In cancer patients, WE may develop because of certain chemotherapeutic agents (especially doxifluridine, ifosfamide, and 5-fluorouracil) [3], malnutrition, and thiamine depletion due to fast-growing tumor cells or gastrointestinal bypass surgery [2]. In the literature, there are a few cases of WE in AML. The diagnosis of WE in cancer patients is difficult because there are many causes of similar symptoms, such as confusion-causing hypoxia, infections, electrolyte imbalance, opioid medications, chemotherapy, brain and meningeal metastases, and delirium [4]. To make a definite diagnosis of WE, it should be clinically suspected. WE may be verified with the measurement of thiamine concentration in blood or erythrocyte transketolase activity; however, these tests are not widely available [3]. Magnetic resonance imaging (MRI) has 93\% specificity and $53 \%$ sensitivity to verify the diagnosis [2]. Bilateral dorsomedial thalamus, tectal plaque, and periaqueductal gray matter signal abnormalities are observed as classical in MRI [5]. WE should be treated empirically with $500 \mathrm{mg}$ of thiamine 3 times per day for 2-3 days. If there is no response, supplementation may be discontinued after 2-3 days. In case an effective response is observed, $250 \mathrm{mg}$ of thiamine should be continued daily until clinical improvement [2].

Thiamine supplementation should definitely be added to TPN or the diets of hematologic malignancy patients with poor oral nutrition. When symptoms such as ataxia, confusion, or ophthalmoplegia appear in these patients, brain MRI should be immediately performed and thiamine infusion should be initiated immediately in the case of strong suspicion.

Keywords: Thiamine, Wernicke's encephalopathy, Acute myeloid leukemia
Anahtar Sözcükler: Tiamin, Wernicke ensefalopatisi, Akut myeloid lösemi

\section{Authorship Contributions}

Concept: Muhammet Maden, Gülsüm Pamuk, Design: Muhammet Maden, Gülsüm Pamuk, Data Collection or Processing: Muhammet Maden, Ercüment Ünlü, Yahya Çelik, Analysis or Interpretation: Muhammet Maden, Gülsüm Pamuk, Ercüment Ünlü, Yahya Çelik, Literature Search: Muhammet Maden, Gülsüm Pamuk, Writing: Muhammet Maden.

Conflict of Interest: The authors of this paper have no conflicts of interest, including specific financial interests, relationships, and/or affiliations relevant to the subject matter or materials included.

\section{References}

1. Papila B, Yildiz O, Tural D, Delil S, Hasiloglu ZI, Ayan F, Papila C. Wernicke's encephalopathy in colon cancer. Case Rep Oncol 2010;3:362-367.

2. Sechi G, Serra A. Wernicke's encephalopathy: new clinical settings and recent advances in diagnosis and management. Lancet Neurol 2007;6:442455.

3. Basu TK, Dickerson JW. The thiamin status of early cancer patients with particular reference to those with breast and bronchial carcinomas. Oncology 1976;33:250-252.

4. Kuo SH, Debnam JM, Fuller GN, de Groot J. Wernicke's encephalopathy: an underrecognized and reversible cause of confusional state in cancer patients. Oncology 2009;76:10-18.

5. Zuccoli G, Siddiqui N, Bailey A, Bartoletti SC. Neuroimaging findings in pediatric Wernicke encephalopathy: a review. Neuroradiology 2010;52:523-529.

\title{
Kaleidoscopic Views in the Bone Marrow: Oxalate Crystals in a Patient Presenting with Bicytopenia
}

Kemik Iliğinde Oksalat Kristalleri Birikimine Bağlı Gelişen Bisitopeni

\author{
Yelda Dere1, Simge Erbil2, Murat Sezak22, Başak Doğanavşargil2, Mümtaz Yılmaz³, Nazan Özsan², Mine Hekimgil2 \\ 1Sıtkı Koçman University Faculty of Medicine, Department of Pathology, Muğla, Turkey \\ 2Ege University Faculty of Medicine, Department of Pathology, Izmir, Turkey \\ ${ }^{3}$ Ege University Faculty of Medicine, Department of Nephrology, Izmir, Turkey
}

To the Editor,

Our patient is a 24-year-old female who was admitted to the nephrology clinic of our hospital with fatigue, weakness, and swelling of the feet. From her medical history, we learned that she had two operations for nephrolithiasis at the ages of 9 and
12, and she underwent renal transplantation in 2013, but she was still on hemodialysis. Laboratory tests showed bicytopenia (anemia and leukopenia) with hemoglobin of $8.2 \mathrm{~g} / \mathrm{dL}$ and white blood cell count of $3800 / \mathrm{mm}^{3}$, and she underwent a bone marrow (BM) biopsy. Microscopically, an almost complete suppression of 
hematopoietic cells with the replacement of BM cells by foreignbody reactive fibrous tissue and numerous birefringent crystalline materials were detected (Figures 1A and 1B). The crystals formed rosettes with needle-like radial extensions surrounded by foreign body-type giant cells. Under polarized light, the crystals formed multicolored rosettes (Figure 1C). In BM aspirates envelope-like crystals were found in the background of a few myeloid cells with normal morphology (Figure 1D). Based on histopathological examination integrated with clinical results, a diagnosis of hypocellular BM associated with crystal deposition concordant with oxalate crystals was made. Because of the absence of genetic tests performed to date, the patient was referred to the genetics department, and after genetic studies the diagnosis of primary hyperoxaluria was confirmed.

Pancytopenia associated with BM infiltration of different deposits is a rare condition mostly associated with amyloidosis or the accumulation of iron. One of the rarest deposits in the BM is oxalate crystals due to hyperoxaluria $[1,2,3]$. Primary hyperoxaluria, a genetic disorder due to mutation in the alanine glyoxylate aminotransferase gene, located on chromosome $2 q 37.3$ and resulting in the conversion of glyoxylate to oxalate, is characterized by increased production of oxalic acid because of the specific liver enzyme deficiency and generally presents with renal stones, renal or liver failure, and oxalosis [4]. Calcium oxalate may even be deposited into various tissues such as those of the retina, peripheral nerves, arterial media, and heart $[4,5]$. The medical history of nephrolithiasis at early ages, characteristic appearance of birefringent crystals forming rosettes in the BM, and the envelope-like forms in the BM aspirates seen in our case supported the diagnosis of primary hyperoxaluria, which is best confirmed by genetic studies and treated with liver transplantation because of the location of the abnormal enzymes in the hepatocytes.

Keywords: Oxalosis, Hyperoxaluria, Bone marrow

Anahtar Sözcükler: Oksalozis, Hiperoksalüri, Kemik iliği

\section{Authorship Contributions}

Concept: Yelda Dere, Mine Hekimgil, Design: Simge Erbil, Yelda Dere, Data Collection or Processing: Mümtaz Yılmaz,

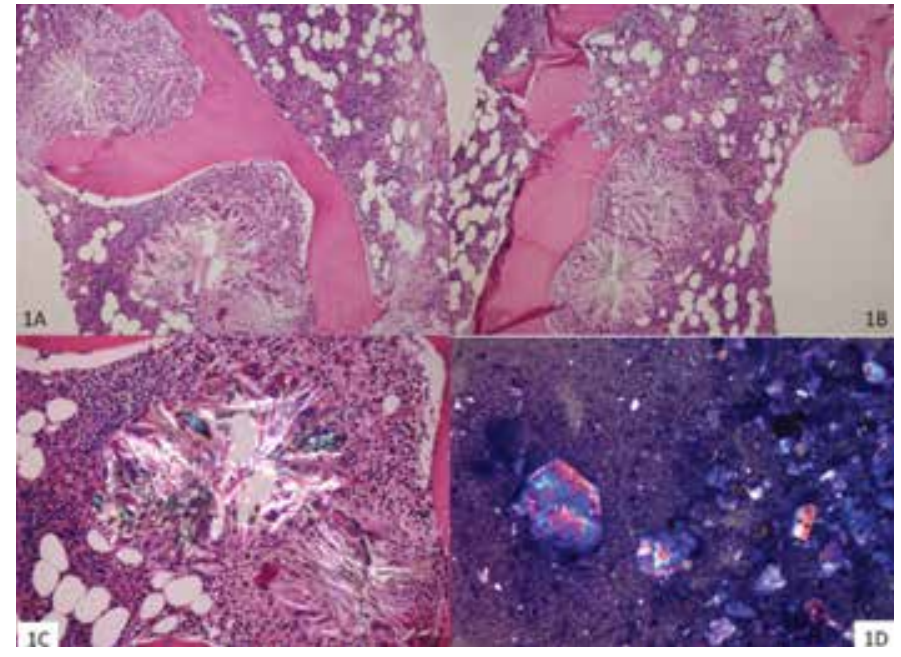

Figure 1. A, B: Characteristic appearance of oxalate crystals in the bone marrow, H\&E, 100x. C: Colorful rosette-like crystal under polarized light, H\&E, 200x. D: Colorful envelope-like crystal in the bone marrow aspirate, Giemsa stain, 100x.

Başak Doğanavşargil, Murat Sezak, Nazan Özsan, Analysis or Interpretation: Mine Hekimgil, Yelda Dere, Simge Erbil, Literature Search: Başak Doğanavşargil, Murat Sezak, Simge Erbil, Writing: Yelda Dere, Mine Hekimgil, Simge Erbil.

Conflict of Interest: The authors of this paper have no conflicts of interest, including specific financial interests, relationships, and/or affiliations relevant to the subject matter or materials included.

\section{References}

1. Walter MJ, Dang CV. Pancytopenia secondary to oxalosis in a 23-year-old woman. Blood 1998;91:4394.

2. Halil 0, Farringdon K. Oxalosis: an unusual cause of leucoerythroblastic anaemia. Br J Haematol 2003;122:2.

3. Taşlı F, Özkök G, Ok ES, Soyer N, Mollamehmetoğlu H, Vardar E. Massive bone marrow involvement in an end stage renal failure case with erythropoietinresistant anemia and primary hyperoxaluria. Ren Fail 2013;35:1167-1169.

4. Hoppe B, Beck BB, Milliner DS. The primary hyperoxalurias. Kidney Int 2009;75:1264-1271.

5. Doganavsargil B, Akil I, Sen S, Mir S, Basdemir G. Autopsy findings of a case with oxalosis. Pediatr Dev Pathol 2009;12:229-232.
Address for Correspondence/Yazışma Adresi: Yelda DERE, M.D., Sıtkı Koçman University Faculty of Medicine, Department of Pathology, Muğla, Turkey

Phone : +905054653198

E-mail : yeldamorgul@gmail.com
Received/Geliş tarihi: July 01, 2015

Accepted/Kabul tarihi: September 07, 2015

DOI: $10.4274 /$ tjh.2015.0256 